\title{
Catabolite repression of $\beta$-glucanase synthesis in Bacillus subtilis
}

\author{
StefFen KRÜGER, Jörg Stülke and MiChael HeckeR* \\ Fachrichtung Biologie, Institut für Mikrobiologie und Molekularbiologie, Ernst-Moritz-Arndt-Universität Greifswald, \\ D-I7487 Greifswald, Jahnstraße 15, Germany
}

(Received 16 December 1992; revised 1 March 1993; accepted 25 March 1993)

\begin{abstract}
$\beta$-Glucanase synthesis in Bacillus subtilis was repressed by glucose and other substrates of glycolysis. Experiments with different pts mutants showed that the phosphoenolpyruvate:sugar phosphotransferase system is not involved in carbon catabolite repression of $\beta$-glucanase synthesis. Carbon catabolite repression of $\beta$-glucanase synthesis was completely abolished in a $c c p A$ mutant. An operator structure similar to those upstream of amyE and the $x y l$ operon was found and was shown by site-directed mutagenesis to be the target for carbon catabolite repression of $\beta$-glucanase synthesis. The presence of this operator on a multi-copy plasmid resulted in a reduced repression of both $\beta$-glucanase and $\alpha$-amylase synthesis. It seems likely that the gene encoding these enzymes are part of one regulon with respect to catabolite repression.
\end{abstract}

\section{Introduction}

In Bacillus subtilis many catabolic enzymes are subject to carbon catabolite repression by glucose and other readily metabolized carbon sources (Fisher \& Sonenshein, 1991). While catabolite repression is a well-understood phenomenon in Escherichia coli (Magasanik \& Neidhardt, 1987), only limited information is available on the mechanism(s) of carbon catabolite repression in $B$. subtilis. The phosphoenolpyruvate: sugar phosphotransferase system (PTS) (Reizer et al., 1988) and glycolytic intermediates (Freese et al., 1974) have been suggested to be involved. Furthermore, Rygus \& Hillen (1992) demonstrated that carbon catabolite repression of the Bacillus megaterium $x y l$ operon correlates with the growth rate that the bacterium can reach on a given sugar.

trans-active mutations have been isolated that led to glucose-resistant synthesis of one or more enzymes. The corresponding genes were defined as ccp A (Henkin et al., 1991), pai (Honjo et al., 1990) and ptsH (Eisermann et al., 1988).

Nicholson \& Chambliss (1985) identified a cis-active mutation, gra-10, in the amy locus of $B$. subtilis that

\footnotetext{
* Author for correspondence. Tel. 0383477271 ext. 522 ; fax 0383 463345 .

Abbreviation: PTS, phosphoenolpyruvate:sugar phosphotransferase system.
}

renders $\alpha$-amylase synthesis glucose-resistant. The gra-10 mutation is a base substitution in a palindromic operator-like structure. Site-directed mutagenesis revealed that this structure is the target of carbon catabolite repression of amyE expression (Weickert \& Chambliss, 1990). A similar structure has been implicated in catabolite repression of the B. subtilis $x y /$ operon (Jacob et al., 1991).

We are interested in the regulation of the $b g / S$ gene of $B$. subtilis encoding endo- $\beta$-1,3-1,4-glucanase (EC 3.2.1.73). In an accompanying study it has been shown that the $b g l S$ gene is temporally activated in response to glucose or amino acid limitations in a GTPpool-dependent manner (Stülke et al., 1993). In this report we demonstrate that carbon catabolite repression of $\beta$-glucanase synthesis is not mediated by the PTS but probably by glycolytic intermediates. An operator structure similar to those of $a m y E$ and the $x y l$ operon was found to be the target site for $b g l S$ carbon catabolite repression.

\section{Methods}

Bacterial strains and plasmids. These are listed in Table 1. The genetic markers of the strains were periodically confirmed.

Plasmid pEC021 was constructed as follows. After deletion of the $2.5 \mathrm{~kb}$ PvuI fragment from plasmid pEGl (Fig. 1 a), yielding pEG026, the $2.9 \mathrm{~kb} H$ indIII fragment of pHV33 (corresponding to pC194) was cloned into the unique $H$ indIII restriction site of pEG026.

Plasmid pEC040 was obtained by inversion of the $3.8 \mathrm{~kb} E c o$ RI fragment of plasmid pHV33-012 (Fig. 1 b) and subsequent deletion of 
Table 1. Bacterial strains and plasmids used in this study

\begin{tabular}{|c|c|c|}
\hline $\begin{array}{l}\text { Strain or } \\
\text { plasmid }\end{array}$ & Genotype or phenotype & Source (reference) \\
\hline \multicolumn{3}{|l|}{ B. subtilis } \\
\hline BG314 & $\operatorname{trpC2}$ aroD120 bgl-35 & Borriss et al. (1986) \\
\hline BGW2 & trpC2 lys-3 ccpA $:: \operatorname{Tn} 917$ & This study \\
\hline GM273 & $\begin{array}{l}\operatorname{trpC2} \text { sac } R:: \operatorname{lac} Z \\
\Delta p t s X H I: \text { erm } C\end{array}$ & Crutz et al. (1990) \\
\hline GM808 & $\operatorname{trpC2} \operatorname{sacR}:$ : lac $Z$ iol & J. Deutscher \\
\hline GR100 & $\operatorname{trpC2}$ gra-100::Tn917 & G. Chambliss \\
\hline IS58 & $\operatorname{trpC2} l y s-3$ & Smith et al. (1980) \\
\hline SA003 & $\begin{array}{l}\text { trpC2 sacR::lacZ iol } \\
\text { ptsHS46A }\end{array}$ & J. Deutscher \\
\hline WLN29 & $\operatorname{trp} C 2$ aroG932 ccpA:: $\operatorname{Tn} 917$ & Henkin et al. (1991) \\
\hline WLN63 & $\begin{array}{l}\text { rpsE rpsL1 sacA321 } \\
\text { gra32::Tn917 }\end{array}$ & G. Chambliss \\
\hline WLN106 & metB5 sacA321 gra-48::Tn917 & G. Chambliss \\
\hline $\begin{array}{l}\text { E. coli } \\
\text { RR1 }\end{array}$ & $\begin{array}{l}\mathrm{F}^{-} \text {mor B mrr hsdS20 ara-14 } \\
\text { proA2 lacYl leu galK2 } \\
\text { rpsL20 xyl-5 mtl-1 supE } 44\end{array}$ & Bolivar et al. (1977) \\
\hline $\begin{array}{l}\text { Plasmids } \\
\text { pHV33 }\end{array}$ & $\mathrm{Tc}^{\mathrm{r}} \mathrm{Ap}^{\mathrm{r}} \mathrm{Cm}^{\mathrm{r}}$ & $\begin{array}{l}\text { Primrose \& Ehrlich } \\
\text { (1981) }\end{array}$ \\
\hline pUC19 & $\operatorname{Ap}^{r}$ & $\begin{array}{l}\text { Yanisch-Perron } \\
\text { et al. }(1985)\end{array}$ \\
\hline pEGl* & $\begin{array}{l}\mathrm{Tc}^{\mathrm{r}} \mathrm{Ap}^{\mathrm{r}} \text { bglA from } B \\
\text { amyloliquefaciens }\end{array}$ & Borriss et al. (1985) \\
\hline pHV33-012† & $\mathrm{Ap}^{\mathrm{r}} \mathrm{Cm}^{\mathrm{r}}$ bglS from B. subtilis & Borriss et al. (1986) \\
\hline $\mathrm{pEC021}$ & $\mathrm{Tc}^{\mathrm{r}} \mathrm{Cm}^{\mathrm{r}}$ bglA & This study \\
\hline pEC040 $\ddagger$ & $\mathrm{Tc}^{\mathrm{I}} \mathrm{Cm}^{\mathrm{r}}$ bglS & This study \\
\hline pEC 041 & $\mathrm{Tc}^{r} \mathrm{Cm}^{\mathrm{r}}$ bglS & This study \\
\hline pEC042 & $\mathrm{Tc}^{\mathrm{r}} \mathrm{Cm}^{\mathrm{r}}$ bglS & This study \\
\hline pUC19/2 & $\mathrm{Ap}^{\mathrm{r}}$ bglS & This study \\
\hline
\end{tabular}

${ }^{*}$ Fig. $1(a), \quad \dagger$ Fig. $1(b) . \quad$ †Fig. $2(a)$.

the $2.5 \mathrm{~kb} \mathrm{PvuI} \mathrm{fragment.} \mathrm{After} \mathrm{religation} \mathrm{of} \mathrm{the} \mathrm{purified} 8.2 \mathrm{~kb}$ fragment the resulting plasmid was pEC040 (Fig. $2 a$ ).

For the purpose of conducting PCR reactions an EcoRI-Pst $\mathrm{I}$ restriction fragment containing the $b g l S$ gene from $\mathrm{pEC} 040$ was cloned between the EcoRI and PstI sites of plasmid pUC19. The resulting plasmid was pUC19/2.

Plasmids pEC041 and pEC042, carrying modified operator sequences, were constructed as follows. Fragments of $1.8 \mathrm{~kb}$ produced in PCR reactions were treated with restriction enzymes EcoRI and PstI, resulting in fragments of $1.7 \mathrm{~kb}$. The purified fragments were ligated with the $6.5 \mathrm{~kb} E c o \mathrm{RI}-P_{s t} \mathrm{I}$ fragment from plasmid pEC040. The resulting plasmid constructions $\mathrm{pEC} 041$ and $\mathrm{pEC} 042$ were verified by DNA sequencing with an oligonucleotide primer located near the translation initiation codon of the $b g I S$ gene.

Culture and growth conditions. B. subtilis cells were grown in amino acid limitation medium (ASM) (Stülke et al., 1993) at $37^{\circ} \mathrm{C}$ under vigorous agitation.

For the determination of growth rates, sodium citrate and potassium glutamate were omitted from the medium, and $\mathrm{KCl}$ was replaced by $\mathrm{NaCl}$. If necessary, antibiotics were added to $1 \mu \mathrm{g} \mathrm{m}^{-1}$ (erythromycin), $5 \mu \mathrm{g} \mathrm{ml}^{-1}$ (chloramphenicol), $12.5 \mu \mathrm{g} \mathrm{ml}^{-1}$ (tetracycline) and $100 \mu \mathrm{g} \mathrm{ml}^{-1}$ (ampicillin).

Media for the production of competent cells of $B$. subtilis were prepared according to Hoch (1991). (a)

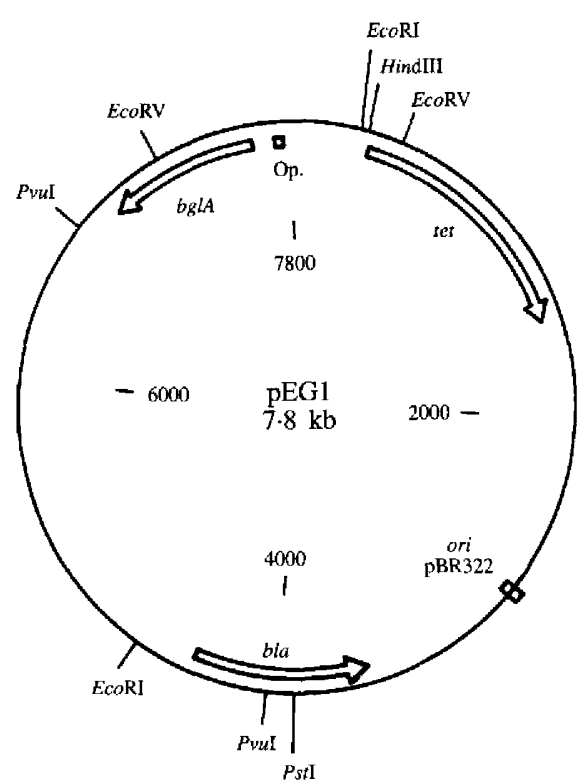

(b)

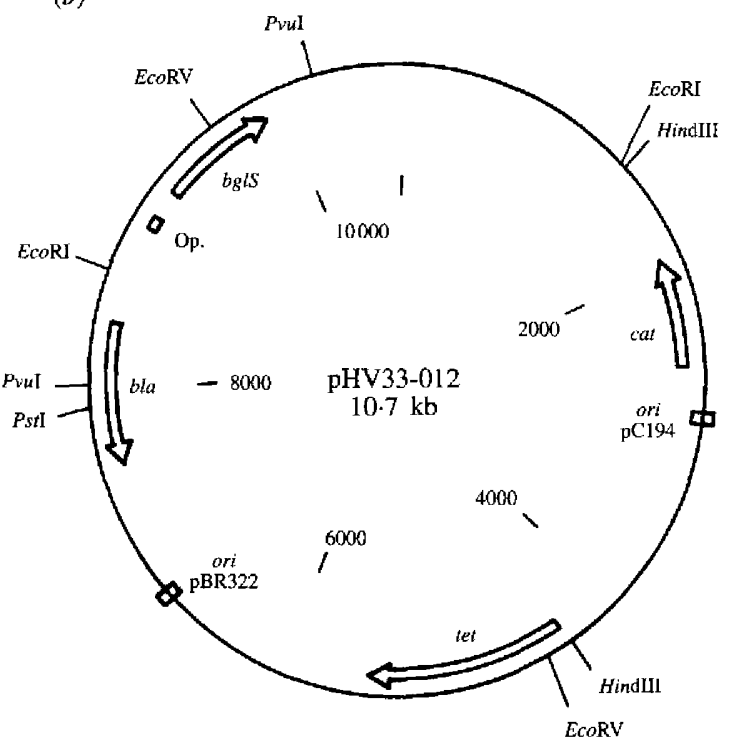

Fig. 1. Physical maps of plasmids pEG1 ( $a$ ) and pHV33-012 (b). These plasmids, containing the $b g l A$ and $b g l S$ genes encoding $\beta$-glucanase of $B$. anyloliquefaciens and $B$. subtilis, respectively, were constructed by Borriss et al. (1985) (pEG1) and Borriss et al. (1986) (pHV33-012). They served for the construction of related plasmids used in this study. Regions of homology to the consensus operator sequence in front of the genes encoding $\beta$-glucanase are indicated $(\mathrm{Op})$

E. coli was grown in nutrient broth containing $8.5 \mathrm{~g}$ peptone, $6.5 \mathrm{~g}$ yeast extract and $10 \mathrm{~g} \mathrm{NaCl}$ per litre, pH 7.4. Agar $(1.5 \%$, w/v) was added for solid media.

Repression experiments. For these experiments the cultures were grown in ASM, divided at an $\mathrm{OD}_{550}$ of 0.8 and the sugars to be tested were added at a final concentration of $0.2 \%$ unless stated otherwise. The residual activity is the percentage of $\beta$-glucanase synthesis in a 
(a)

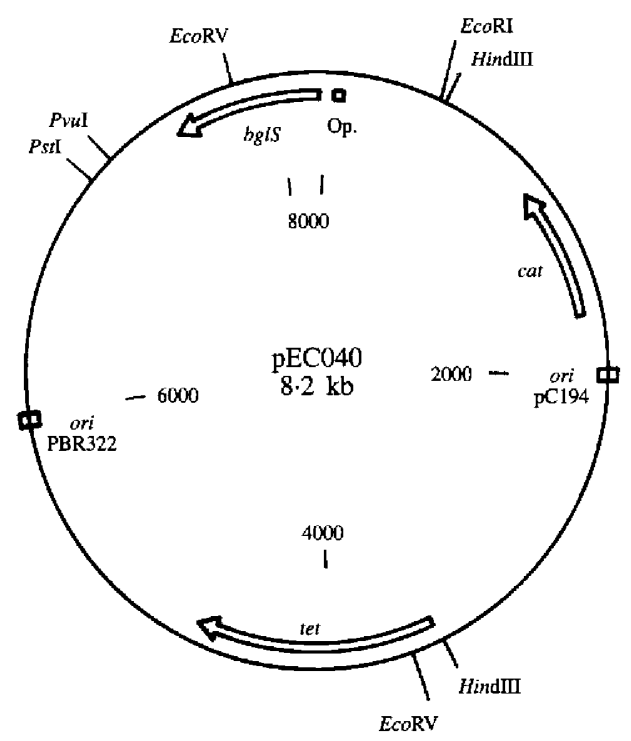

(b)

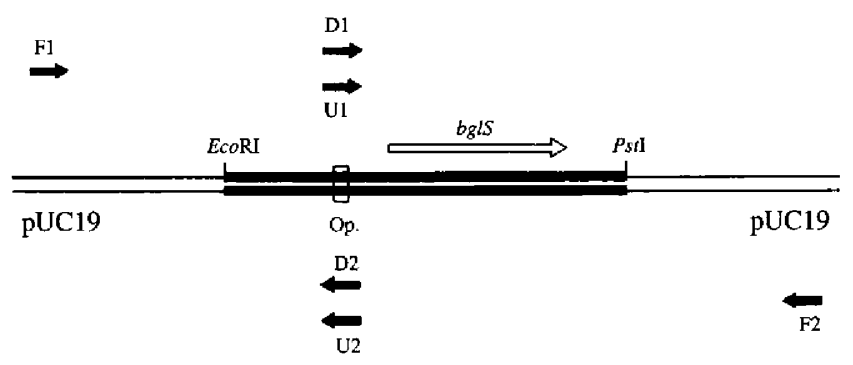

Fig. 2. (a) Physical map of plasmid pEC040. The position of the wildtype operator (Op.) upstream of the $b g l S$ gene encoding $\beta$-glucanase is shown. (b) Scheme of primer arrangement in plasmid pUC19/2. The positions of the bglS gene and the operator (Op.) are shown. The bold lines represent the $1.7 \mathrm{~kb}$ fragment obtained from plasmid pEC040. A convenient procedure for PCR reactions was achieved via this strategy.

culture containing a sugar compared to the control culture after $2.5 \mathrm{~h}$ of stationary phase.

Oligonucleotides. The sequences of the mutagenic oligonucleotides spanning the postulated operator structure are given below, with the mismatch bases underlined:

$$
\begin{aligned}
& \text { U1, 5'-d(GAATCATGTAAGCGCAACATAG)-3' } \\
& \text { U2, 5'-d(GCGTTTTCTATGTTGCGCTTACATG)-3' } \\
& \text { D1, 5'-d(GAATCATGTAAGATCAATATAG)-3' } \\
& \text { D2, 5'-d(GCGTTTTCTATATTGATCTTACATG)-3' }
\end{aligned}
$$

The flanking primers, $F 1$ and $F 2$, that hybridize upstream and downstream, respectively, of the polylinker region of plasmid pUC19, have the following sequences:

\section{F1, $5^{\prime}$-d(AAAGGGGGATGTGCTGCAAGGCG)-3 F2, 5'-d(GCTTCCGGCTCGTATGTTGTGTG)-3'}

The arrangement of the primers used in this study is shown schematically in Fig. $2(b)$.
General recombinant DNA techniques. Standard procedures were used for extracting plasmids from E. coli and B. subtilis (Holmes \& Quigley, 1981; Sambrook et al., 1989). Restriction enzymes and T4 DNA ligase were used according to the recommendations of the manufacturer. DNA fragments were purified from agarose gels by using the GeneClean II kit (Bio 101).

Chromosomal DNA was isolated as described by Meade et al. (1982).

The $\mathrm{CaCl}_{2}$ method (Sambrook et al., 1989) was used to transform $E$. coli RR1. B. subtilis strains were transformed with plasmid or chromosomal DNA using naturally competent cells (Hoch, 1991).

DNA sequences were determined by the dideoxy-chain termination method (Sanger et al., 1977) with plasmid DNA as template and modified T7 DNA polymerase (US Biochemicals Corp.).

Generation of PCR products. PCRs were carried out using Taq polymerase (Promega). Amplification of DNA fragments from plasmid template was achieved by adding $200 \mathrm{ng}$ of template DNA, $50 \mathrm{~mm}-$ $\mathrm{KCl}, 10 \mathrm{~mm}-\mathrm{Tris} / \mathrm{HCl} \mathrm{pH} 9.0,1.5 \mathrm{mM}-\mathrm{MgCl}_{2}, 0.01 \%$ (w/v) gelatin, $0.1 \%(\mathrm{v} / \mathrm{v})$ Triton X-100, $200 \mu \mathrm{M}$ of each dNTP, $25 \mathrm{pmol}$ of each primer and 2.5 units of Taq polymerase in a final volume of $100 \mu \mathrm{l}$. The samples were overlaid with $60 \mu \mathrm{l}$ light mineral oil (Sigma).

In each mutagenic strategy two overlapping gene fragments were synthesized in separate primary amplifications with plasmid pUC19/2 as template. PCR conditions were chosen as follows: denaturation $1 \mathrm{~min}, 94^{\circ} \mathrm{C}$; annealing $1 \mathrm{~min}, 50^{\circ} \mathrm{C}$; extension $3 \mathrm{~min}, 72^{\circ} \mathrm{C} ; 30$ cycles. For amplification of $S^{\prime}$ fragments of the $b g l S$ gene, mutagenic primers $\mathrm{U} 2$ or D2 and the flanking primer F1 were used. The $3^{\prime}$ part of the bglS gene was amplified using mutagenic primers $\mathrm{Ul}$ or $\mathrm{Dl}$ and the flanking primer F2.

In the second round of PCR, equivalent amounts of purified overlapping gene fragments from the two primary amplifications were mixed in samples as described above. Twenty PCR cycles of $94^{\circ} \mathrm{C}$ for $1 \mathrm{~min}, 45^{\circ} \mathrm{C}$ for $2 \mathrm{~min}$ and $72^{\circ} \mathrm{C}$ for $3 \mathrm{~min}$ were carried out to produce full-length DNA fragments using primers $F 1$ and $F 2$.

The products of the reactions were analysed on an agarose gel containing $1 \%(\mathrm{w} / \mathrm{v})$ agarose and $0.5 \mu \mathrm{g}$ ethidium bromide $\mathrm{ml}^{-1}$ in Tris/borate buffer ( $90 \mathrm{~mm}$-Tris/borate, $1 \mathrm{mm-EDTA,} \mathrm{pH} \mathrm{8.0).}$

Enzyme assays. $\beta$-Glucanase activities were assayed by the dinitrosalicylic acid method as described previously (Stülke et al., 1993). One enzyme unit was defined as $1 \mathrm{~mol}$ glucose equivalent produced $\left(\mathrm{OD}_{550} \text { unit }\right)^{-1}$ and $\mathrm{ml}^{-1} \mathrm{~s}^{-1}$ (= 1 kat).

The measurement of $\alpha$-amylase activity was based on a modification of the procedure of Tsukagoshi et al. (1984). A $150 \mu 1$ portion of culture supernatant was mixed on ice with $100 \mu \mathrm{l} 0.2 \%(\mathrm{w} / \mathrm{v})$ soluble starch in 100 mM-sodium acetate pH 6.0 and then incubated at $37^{\circ} \mathrm{C}$ for $60 \mathrm{~min}$. The reaction was stopped by adding $50 \mu \mathrm{l}$ of $0.2 \%$ (w/v) $\mathrm{I}_{2}, 1 \%(\mathrm{w} / \mathrm{v})$ $\mathrm{KI}$ in $1.75 \mathrm{M}$-sodium acetate $\mathrm{pH} 4.0$. After the addition of $1 \mathrm{ml}$ distilled water the absorbance at $570 \mathrm{~nm}$ was compared with that of a blank (same composition as above but no incubation). One unit corresponds to the amount of enzyme necessary for degradation of $6 \mathrm{mg} \mathrm{starch} \mathrm{h}^{-1}$.

\section{Results}

Carbon catabolite repression of $\beta$-glucanase synthesis by various sugars

The repression of $\beta$-glucanase synthesis exerted by the carbon sources glucose, fructose, sucrose, glucitol, glycerol, ribose, xylose, gluconate and methyl $\alpha$-glucoside (final concentration $0.2 \%$ ) in $B$. subtilis IS58 was determined (Table 2). The strongest repression was 
Table 2. Carbon catabolite repression of $\beta$-glucanase synthesis in IS58

The $\beta$-glucanase activity in $B$. subtilis IS 58 was 0.62 nkat under unrepressed conditions. Experiments were performed three times.

Representative results are shown. NA, Not applicable.

\begin{tabular}{lcc}
\hline \hline Sugar & $\begin{array}{c}\text { Residual } \\
\text { activity } \\
(\%)\end{array}$ & $\begin{array}{c}\text { Specific } \\
\text { growth } \\
\text { rate, } \mu \\
\left(\mathbf{h}^{-1}\right)\end{array}$ \\
\hline Glucose & 7 & $1 \cdot 25$ \\
Fructose & 15 & $1 \cdot 25$ \\
Sucrose & 13 & $1 \cdot 25$ \\
Glucitol & 54 & $1 \cdot 25$ \\
Glycerol & 26 & $1 \cdot 25$ \\
Ribose & 180 & $0 \cdot 71$ \\
Gluconate & 130 & $1 \cdot 11$ \\
Methyl $\alpha-$ & 100 & NA \\
glucoside & & \\
\hline
\end{tabular}

found with glucose $(7 \%$ residual activity); no repression was obtained with ribose and gluconate. The addition of glucose to a final concentration of $0.4 \%$ resulted in complete repression of $\beta$-glucanase synthesis. No repression was found with the slowly metabolizable PTS substrate methyl $\alpha$-glucoside (Table 2). The addition of this sugar led to a cessation of growth and to an immediate induction of $\beta$-glucanase synthesis (data not shown).

\section{Catabolite repression of $\beta$-glucanase synthesis in pts mutants}

For a more detailed analysis of PTS involvement in carbon catabolite repression, $\beta$-glucanase synthesis was determined in PTS mutants in the presence of either the PTS sugar glucose or the non-PTS carbohydrate glucitol. In strain GM273 ( $\Delta p t s G H I::$ erm $C$ ), glucitol repressed $\beta$ glucanase synthesis fourfold. With the ptsHS46A mutant SA003 no repression was observed with glucose, but the residual activity with glucitol was $57 \%$, similar to that in the wild-type strain GM808 (Table 3).

Determinations of growth rates of strains GM808, GM273 and SA003 with either glucose or glucitol as single carbon sources revealed that GM273 did not grow on glucose, and strain SA003 grew more slowly on glucose than on glucitol (Table 3).

\section{Expression of bglS in gra mutants}

Studies to find the trans-acting element of catabolite repression of $\alpha$-amylase synthesis led to the isolation of four glucose-resistant mutants, among them a $\operatorname{ccpA}$ mutant (Henkin et al., 1991).

Experiments were performed to determine glucose repression of $\beta$-glucanase synthesis and growth rates of these mutants (Table 4). $\beta$-Glucanase synthesis was repressed twofold in the $\operatorname{ccp} A$ mutant WLN29 in the presence of glucose. In the gra mutant strains glucose repression of $\beta$-glucanase synthesis was comparable to that of $B$. subtilis IS58.

The insufficient utilization of glucose or glycerol led us to ask whether $c c p A$ is the only mutation of $B$. subtilis WLN29 affecting growth and catabolite repression. To transfer the $c c p A$ allele into a defined genetic background, chromosomal DNA of WLN29 was purified and used to transform strain IS58. Transformants carrying a ccpA::Tn $9 / 7$ insertion were isolated by selection for erythromycin resistance. The resulting strain was BGW2. Neither glucose nor glycerol repressed the synthesis of $\beta$ glucanase (Table 4 ) or $\alpha$-amylase (data not shown) in this strain.

\section{Identification of a regulon}

Using the multi-copy vector pEC040 transformed into strain IS58 a more than 100-fold increase in $\beta$-glucanase synthesis in comparison with IS58 and IS58(pHV33) was

Table 3. Repression of synthesis of $\beta$-glucanase in pts mutants

Representative results of three separate experiments are shown.

\begin{tabular}{|c|c|c|c|c|c|}
\hline \multirow[b]{2}{*}{ Strain } & \multirow[b]{2}{*}{$\begin{array}{c}\beta \text {-Glucanase } \\
\text { activity* } \\
\text { (nkat) }\end{array}$} & \multicolumn{2}{|c|}{ Glucose } & \multicolumn{2}{|c|}{ Glucitol } \\
\hline & & $\begin{array}{c}\text { Residual } \\
\text { activity } \\
(\%)\end{array}$ & $\begin{array}{l}\text { Specific } \\
\text { growth } \\
\text { rate, } \mu \\
\left(\mathrm{h}^{-1}\right)\end{array}$ & $\begin{array}{c}\text { Residual } \\
\text { activity } \\
(\%)\end{array}$ & $\begin{array}{c}\text { Specific } \\
\text { growth } \\
\text { rate, } \mu \\
\left(\mathrm{h}^{-\mathrm{i}}\right)\end{array}$ \\
\hline $\begin{array}{l}\text { GM273 } \\
(\Delta p t s G H I: \text { erm })\end{array}$ & $1 \cdot 14$ & - & - & 24 & 0.53 \\
\hline $\begin{array}{l}\mathrm{SA} 003 \\
(p t s H \mathrm{~S} 46 \mathrm{~A})\end{array}$ & $1 \cdot 51$ & 98 & 1.0 & 57 & $1 \cdot 1$ \\
\hline $\begin{array}{l}\text { GM808 } \\
\left(p t s^{+}\right)\end{array}$ & 1.5 & 20 & $1 \cdot 25$ & 53 & $1 \cdot 25$ \\
\hline
\end{tabular}

*Under unrepressed conditions. 
Table 4. Glucose repression of synthesis of $\beta$-glucanase in ccpA and gra mutants and IS58

Experiments were repeated at least twice; representative data are shown. ND, Not determined.

\begin{tabular}{|c|c|c|c|c|c|}
\hline \multirow[b]{2}{*}{ Strain } & \multirow{2}{*}{$\begin{array}{c}\beta \text {-Glucanase } \\
\text { activity* } \\
\text { (nkat) }\end{array}$} & \multirow{2}{*}{$\begin{array}{c}\text { Residual } \\
\text { activity } \\
(\%)\end{array}$} & \multicolumn{3}{|c|}{ Specific growth rate, $\mu\left(\mathrm{h}^{-1}\right)$} \\
\hline & & & Citrate & Glucose & Glycerol \\
\hline $\begin{array}{l}\text { WLN29 } \\
(\text { cсpA::Tn917) }\end{array}$ & $1 \cdot 31$ & 50 & $0 \cdot 62$ & $0 \cdot 45$ & 0.42 \\
\hline $\begin{array}{l}\text { WLN63 } \\
\text { (gra-32::Tn917) }\end{array}$ & $0 \cdot 4$ & 12 & 0.62 & $1 \cdot 1$ & ND \\
\hline $\begin{array}{l}\text { WLN106 } \\
\text { (gra-48::Tn917) }\end{array}$ & 0.64 & 9 & 0.5 & 0.71 & ND \\
\hline $\begin{array}{l}\text { GR100 } \\
\quad(\text { gra-100::Tn917) }\end{array}$ & $1 \cdot 71$ & 15 & $0 \cdot 25$ & 0.62 & ND \\
\hline $\begin{array}{l}\text { BGW } 2 \uparrow \\
(\operatorname{ccp} A:: \operatorname{Tn} 9 / 7)\end{array}$ & $2 \cdot 8$ & 127 & ND & 0.75 & 0.68 \\
\hline $\begin{array}{l}\text { IS58 } \\
\left(\text { ccp A } A^{+} \mathrm{gra}^{+}\right)\end{array}$ & 0.62 & 7 & $1 \cdot 0$ & $1 \cdot 25$ & 1.25 \\
\hline
\end{tabular}

* Under unrepressed conditions.

$\dagger$ In repression experiments using $0.2 \%$ (w/v) glycerol a residual activity of $148 \%$ was measured.

Table 5. Effect of a multi-copy operator on carbon catabolite repression of $\beta$-glucanase and $\alpha$-amylase synthesis in IS58

Three separate experiments were performed and representative results are shown.

\begin{tabular}{cccccc}
\hline \hline & \multicolumn{2}{c}{$\beta$-Glucanase } & & \multicolumn{2}{c}{$\alpha$-Amylase } \\
\cline { 2 - 3 } \cline { 5 - 6 } Plasmid & $\begin{array}{c}\text { Enzyme } \\
\text { activity* } \\
\text { (nkat) }\end{array}$ & $\begin{array}{c}\text { Residual } \\
\text { activity } \\
(\%)\end{array}$ & & $\begin{array}{c}\text { Enzyme } \\
\text { activity* } \\
\text { (units per } \\
\text { OD }_{550} \text { unit) }\end{array}$ & $\begin{array}{c}\text { Residual } \\
\text { activity } \\
(\%)\end{array}$ \\
\hline pHV33 & 0.62 & 7 & & 0.15 & 26 \\
pEC040 & 147.14 & $5 \cdot 7$ & & 0.15 & 27 \\
\hline \hline
\end{tabular}

* Under unrepressed conditions.

$\dagger$ Media supplemented with $0.2 \%(\mathrm{w} / \mathrm{v})$ glucose.

$\$$ Media supplemented with $0.4 \%$ (w/v) glucose.
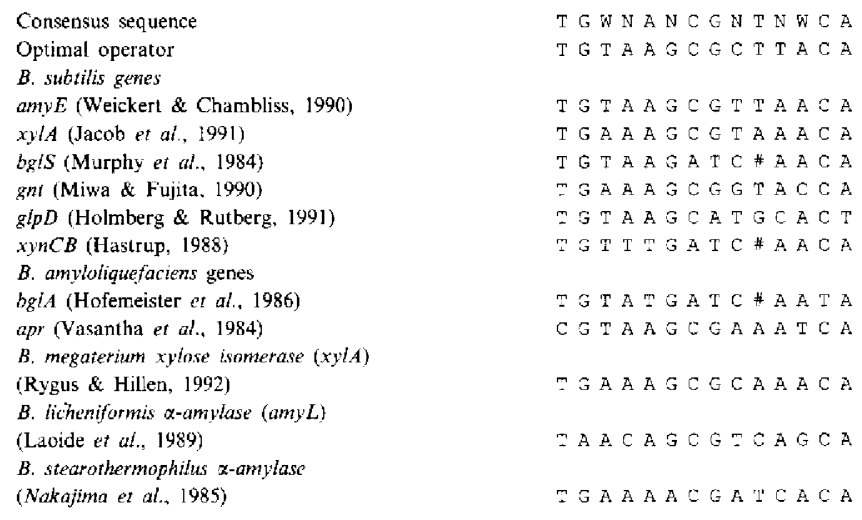

Fig, 3. Comparison of sequences with homology to the consensus operator. ( $\mathrm{W}=\mathrm{A}$ or $\mathrm{T} ; \mathrm{N}=$ any base; \# = gap). observed. As shown in Table 5 repression of $b g l S$ expression was lowered when the operator was present in multiple copies. It was assumed that an active transacting element occurs in limiting amounts under experimental conditions.

Moreover, the presence of plasmid pEC040 also influenced the stringency of carbon catabolite repression of $\alpha$-amylase synthesis (Table 5 ). $\alpha$-Amylase synthesis was not efficiently repressed in the presence of $0.2 \%$ glucose. Bacteria were grown in ASM under repressing $(0.4 \%$ glucose $)$ and non-repressing conditions and $\alpha$ amylase activity measured. amyE gene expression was repressed fourfold in IS58 and IS58(pHV33), whereas in IS58( $\mathrm{pEC} 040)$ a repression factor of only 2.5 was obtained.

\section{Site-directed mutagenesis and analysis of mutants}

An operator-like sequence was found via sequence alignment of the $a m y O$ operator with the upstream region of the $b g l S$ gene (Weickert \& Chambliss, 1990). The postulated operator is located between -47 and -35 (with reference to the translation initiation codon) and shows three mismatch bases and one gap in comparison with amyO (Fig. 3).

To analyse the contribution of the operator-like sequence to catabolite repression of $\beta$-glucanase synthesis, site-directed mutagenesis using the recombinant PCR technique was performed. Two sets of primers were synthesized (U1/U2 and D1/D2) containing nucleotides representing the base substitutions to mutagenize the region of homology. The former primer set should generate an operator allowing stronger catabolite re- 
Table 6. Effect of base substitutions on $\beta$-glucanase expression

Experiments were done at least twice; representative results are shown.

\begin{tabular}{llcc}
\hline \hline Plasmid strain & Operator sequence & $\begin{array}{c}\beta \text {-Glucanase } \\
\text { activity* } \\
\text { (nkat) }\end{array}$ & $\begin{array}{c}\text { Residual } \\
\text { activity } \\
(\%)\end{array}$ \\
\hline IS58 $\ddagger$ & TGTAAGATCAACA & 0.62 & 0 \\
BG314(pEC040) & TGTAAGATCAACA & $84 \cdot 7$ & 61 \\
BG314(pEC041) & TGTAAGATCAATA & $484 \cdot 7$ & 94 \\
BG314(pEC042) & TGTAAGCGCAAACA & $27 \cdot 3$ & 48 \\
BG314(pEC021) & TGTATGATCAATA & 81.0 & 117 \\
\hline \hline
\end{tabular}

* Under unrepressed conditions.

$\dagger$ The glucose concentration used in these experiments was $0.4 \%$.

$\ddagger$ Control strain, in which the bglS system only occurs on the chromosome.

pression than the wild-type sequence ('up' mutation). The latter was used to form a structure abolishing the effect of catabolite repression of $\beta$-glucanase ('down' mutation). The primary amplifications and the fusion reactions were done as described above. Mutants were screened by sequence analysis and a frequency of mutation of $75 \%$ was obtained. In addition to base substitutions according to the primer design other singlebase changes occurred (frequency $0.25 \%$ ).

The recombinant plasmids pEC041 and pEC042, representing the 'down' and 'up' mutations, respectively, were transformed into B. subtilis BG314 and the effect of glucose on $\beta$-glucanase expression was measured. In the case of BG314(pEC041) glucose repression was nearly completely abolished, whereas in $\mathrm{BG} 314(\mathrm{pEC} 042)$ the repression of $\beta$-glucanase synthesis was stronger than in the wild-type BG314(pEC040) (Table 6).

The $\beta$-glucanase gene of Bacillus amyloliquefaciens shows extensive homology with that of $B$. subtilis (Hofemeister et al., 1986). The operator sequence for catabolite-mediated repression of $b g l S$ can also be found in the $b g l A$ system but involves two further base changes (Fig. 3). Plasmid pEC021, carrying the entire bglA gene and the upstream region, was transformed into $B$. subtilis BG314. Catabolite repression of $\beta$-glucanase synthesis was fully abolished in this strain as in the 'down' mutant BG314(pEC041) (Table 6).

\section{Discussion}

Carbon catabolite repression is a well-documented phenomenon in bacteria, but its mechanism in B. subtilis is poorly understood.

While the EIIA ${ }^{\mathrm{Glc}}$ of the PTS is the sensor of glucose availability in $E$. coli, this is probably not the case in $B$. subtilis. The repression data from experiments with PTS and non-PTS carbohydrates, and methyl $\alpha$-glucoside, and with PTS mutants indicated that the PTS is not involved in carbon catabolite repression of $\beta$-glucanase synthesis in $B$. subtilis.

The HPr proteins of Gram-positive bacteria are unique in possessing a second phosphorylation site (Ser-46, Reizer et al., 1989) besides the ubiquitous phosphorylation site His-15. A substitution of this Ser-46 by an alanine renders the expression of the $B$. subtilis gluconate operon glucose-resistant. The same applied to $\beta$-glucanase synthesis, but repression by the non-PTS carbohydrate glucitol was not influenced by the $p t s H$ mutation. Furthermore, the reduced growth rate of the $p t s H$ mutant SA003 indicates that this mutant might somehow be defective in glucose uptake and/or utilization.

Only those sugars that are metabolized via the glycolytic pathway (Table 2) led to catabolite repression of $\beta$-glucanase synthesis. Therefore it is possible that the intracellular signal for carbon catabolite repression is derived from glycolytic intermediates. This hypothesis is in accordance with the data concerning the gra mutants. The only pleiotropic mutation, $c c p A$, resulted in a very slow growth on both glucose and glycerol (Table 4). The glycerol-resistant expression of $a m y E$ is in contrast to previously published observations (Henkin et al., 1991). This might be due to the genetic backgrounds of the strains studied. Indications of the involvement of glycolysis in carbon catabolite repression were also obtained by Freese et al. (1974).

The target of carbon catabolite repression of $\beta$ glucanase expression in $\boldsymbol{B}$. subtilis was identified by sitedirected mutagenesis. Data obtained by Weickert \& Chambliss (1990) for the cis-active site of $\alpha$-amylase repression were used to construct defined $b g l S$ operator mutants. The results (Table 6) clearly indicate that the postulated sequence is indeed the target for glucose repression of $\beta$-glucanase synthesis. Preliminary experiments proved the same to apply to repression by glucitol. In the case of $\mathrm{pEC} 042$, representing the operator 'up' mutation, an extra $\mathrm{A}$ at position 11 occurred which might be caused by the Taq polymerase during recombinant PCR (Table 6). On the other hand this operator consists of 14 base pairs, providing an additional adjustment to the consensus operator sequence. A region of weak homology to the consensus operator sequence is present in front of the bglA gene of $B$. amyloliquefaciens (Fig. 3). That region is very similar to the operator generated in the 'down' mutation approach but includes a further base substitution at position 5 . It was not surprising that no catabolite repression of $\beta$ glucanase synthesis could be detected with strain BG314(pEC021) (Table 6).

The presence of the multi-copy plasmid $\mathrm{pEC} 040$ 
resulted in an increase of enzyme activity (about 140fold). The lower activity obtained with strains harbouring pEC042 may be due to an amino acid exchange (Lys $\rightarrow$ Glu) in the leader peptide of the $\beta$-glucanase leading to an inefficient transport through the cytoplasmic membrane. The reason for the high enzyme level in the case of pEC041 will have to be determined in further investigations.

Strains BG314 and IS58 differed in catabolite repression efficiency. Enzyme synthesis was less repressed in strain BG314 than in IS58. An additional mutation in BG314 is thought to be the cause of that behaviour.

The dependence of catabolite repression on the concentration of the carbon source is another interesting observation. Both $\beta$-glucanase and $\alpha$-amylase syntheses were more strongly repressed by $0.4 \%$ glucose in comparison to $0.2 \%$ (data not shown).

The phenomenon of the titration of a trans-factor due to the presence of the multi-copy plasmid pEC040 observed for $\beta$-glucanase synthesis (Tables 5 and 6) made it possible to investigate whether amyE expression is repressed by the same trans-factor. Plasmid pEC040 carries the entire $b g I S$ gene and the operator for catabolite repression of $b g l S$ expression. The binding of the postulated repressor to its operator sequence on the multi-copy plasmid pEC040 should also influence $\alpha$ amylase repression. The results (Table 5) indicate that one type of negative regulator is responsible for glucose repression of both amyE and $b g l S$ expression. In addition, catabolite repression of $\beta$-xylosidase (encoded by $x y n B$; Hastrup, 1988) is reduced by the presence of multicopy operator (C. Lindner, personal communication). Therefore all three genes may be part of one carbon catabolite repression regulon.

With the data presented in this paper the molecular mechanism of carbon catabolite repression for another degradative enzyme has been established. A cis-active sequence similar to those previously identified as targets of carbon catabolite repression of $a m y E$ and the $x y l$ operon (Weickert \& Chambliss, 1990; Jacob et al., 1991) was found to be the regulatory element for $b g l S$ catabolite repression. Sequences resembling the consensus operator are present in front of many catabolic genes of Bacillus spp. (Fig. 3). All these genes are possibly part of a global carbon catabolite repression regulon. The identification of the trans-factor will lead to a more precise understanding of that regulatory phenomenon.

A. Tschirner and A. Arelt are acknowledged for their excellent technical assistance. We are grateful to W. Hillen for critical discussions and to R. Borriss for the introduction to recombinant PCR. J. Deutscher is acknowledged for the gift of strains. This work was supported by the Deutsche Forschungsgemeinschaft and the Fonds der Chemischen Industrie.

\section{References}

Bolivar, F., Rodriques, R. L., Greener, P. J., Betlach, M. C., Heyneker, H. L., Boyer, H. W., Crosa, J. H. \& Falkow, S. (1977). Construction and characterization of new cloning vehicles. I1. A multipurpose cloning system. Gene 2, 95-133.

Borriss, R., BÄumlein, H. \& Hofemeister, J. (1985). Expression in Escherichia coli of a cloned $\beta$-glucanase gene from Bacillus amyloliquefaciens. Applied Microbiology and Biotechnology 22, 63-71.

Borriss, R., SÜss, K. H., Süss, M., Manteuffel, R. \& Hofemeister, J. (1986). Mapping and properties of bgl ( $\beta$-glucanase) mutants of Bacillus subtilis. Journal of General Microbiology 132, 431-442.

Crutz, A. M., Steinmetz, M., Aymerich, S., Richter, R. \& Lecoq, D. (1990). Induction of levansucrase in Bacillus subtilis: an antitermination mechanism negatively controlled by the phosphotransferase system. Journal of Bacteriology 172, 1043-1050.

Eisermann, R., DeUtscher, J., Gonzy-TReboul, G. \& Hengstenberg, W. (1988). Site-directed mutagenesis with the ptsH gene of Bacillus subtilis. Isolation and characterization of heat-stable proteins altered at the ATP-dependent regulatory phosphorylation site. Journal of Biological Chemistry 263, 17050-17054.

Fisher, S. H. \& Sonenshein, A. L. (1991). Control of carbon and nitrogen metabolism in Bacillus subtilis. Annual Review of Microbiology 45, 107-135.

Freese, E., Ichikawa, T., Oh, Y. K., Freese, E. B. \& Prasad, C (1974). Deficiencies or excesses of metabolites interfering with differentiation. Proceedings of the National Academy of Sciences of the United States of America 71, 4188-4193.

HASTRUP, S. (1988). Analysis of the Bacillus subtilis xylose regulon. In Genetics and Biotechnology of Bacilli II, pp. 79-83. Edited by A. T. Ganesan \& J. A. Hoch. New York: Academic Press.

Henkin, T. M., Grundy, F. J., Nicholson, W. L. \& Chambliss, G. H. (1991). Catabolite repression of alpha-amylase gene expression in Bacillus subtilis involves a trans-acting gene product homologous to the Escherichia coli lacI and galR repressors. Molecular Microbiology 5, 575-584

Hoch, J. A. (1991). Genetic analysis in Bacillus subtilis. Methods in Enzymology 204, 305-320.

Hofemeister, J., KurTZ, A., Borriss, R. \& KNowles, J. (1986). The $\beta$ glucanase from Bacillus amyloliquefaciens shows extensive homology with that of Bacillus subtilis. Gene 49, 177-187.

HOLMBERG, C. \& RUTBERG, B. (1991). Expression of the gene encoding glycerol-3-phosphate dehydrogenase ( $g l p D)$ in Bacillus subtilis is controlled by antitermination. Molecular Microbiology 5, 2891-2900.

Holmes, P. S. \& Quigley, M. (1981). A rapid boiling method for the preparation of bacterial plasmids. Analytical Biochemistry 114, $187-193$.

Honjo, M., Nakayama, A., Fukazawa, K., Kawamura, K., Ando, K., HorI, M. \& FuruTanI, Y. (1990). A novel Bacillus subtilis gene involved in negative control of sporulation and degradative-enzyme production. Journal of Bacteriology 172, 1783-1790.

JaCOB, S., Allmannsberger, R., Gärtner, D. \& Hillen, W. (1991). Catabolite repression of the operon for xylose utilization from Bacillus subtilis W23 is mediated at the level of transcription and depends on a cis site in the xylA reading frame. Molecular and General Genetics 229, 189-196.

LaOide, B. M., Chambliss, G. H. \& MCConnell, D. J. (1989). Bacillus licheniformis $\alpha$-amylase gene, amyL, is subject to promoter-independent catabolite repression in Bacillus subtilis. Journal of Bacteriology 171, 2435-2442.

Magasanik, B. \& NeIDHARDT, F. C. (1987). Regulation of carbon and nitrogen utilization. In Escherichia coli and Salmonella typhimurium: Cellular and Molecular Biology, pp. 1318-1325. Edited by F.C. Neidhardt, J. L. Ingraham, K. B. Low, B. Magasanik, M. Schaechter \& H. E. Umbarger, Washington, DC: American Society for Microbiology.

Meade. H. M., Long, S. R., Ruvkun, G. B., Brown, S. E. \& Ausubel, F. M. (1982). Physical and genetic characterization of symbiotic and auxotrophic mutants of Rhizobium meliloti induced by transposon Tn5 mutagenesis. Journal of Bacteriology 149, 114-122.

Miwa, Y. \& Fujita, Y. (1990). Determination of the cis sequence 
involved in catabolite repression of the Bacillus subtilis gnt operon - implication of a consensus sequence in catabolite repression in the genus Bacillus. Nucleic Acids Research 18, 7049-7053.

Murphy, N. D., MCConnell, D. J. \& Cantwell, B. A. (1984). The DNA sequence of the gene and genetic control sites for the excreted Bacillus subtilis enzyme $\beta$-glucanase. Nucleic Acids Research 12, 5355-5367.

NaKaIMA, R., ImANaKa, T. \& Aiba, S. (1985). Nucleotide sequence of the Bacillus stearothermophilus $\alpha$-amylase gene. Journal of Bacteriology 163, 401-406.

Nicholson, W. L. \& Chambliss, G. H. (1985), Isolation and characterization of a cis-acting mutation conferring catabolite repression resistance to $x$-amylase synthesis in Bacillus subtilis. Journal of Bacteriology 161, 875-881.

Primrose, S. B. \& Ehrlich, S. D. (1981). Isolation of plasmid deletion mutants and study of their instability. Plasmid 6, 193-201.

Reizer, J., Saier, M. H., Deutscher, J., Grenier, F., Thompson, J. \& HengsteneterG, W. (1988). The phosphoenolpyruvate:sugar phosphotransferase system in gram-positive bacteria: properties, mechanism, and regulation. CRC Critical Reviews in Microbiology $\mathbf{1 5}$, $297-338$.

Reizer, J., Deutscher, J. \& SAIER, M. H. (1989). Metabolite-sensitive, ATP-dependent, protein kinase-catalyzed phosphorylation of $\mathrm{Hpr}$, a phosphocarrier protein of the phosphotransferase system in Grampositive bacteria. Biochimie 71, 989-996.

Rygus, T. \& Hillen, W. (1992). Catabolite repression of the $x y l$ operon in Bacillus megaterium. Journal of Bacteriology 174, 30493055 .
Sambrook, J., Fritsch, E. F. \& Maniatis, T. (1989). Molecular Cloning : a Laboratory Manual, 2nd edn. Cold Spring Harbor, NY: Cold Spring Harbor Laboratory.

Sanger, F., Nicklen, S. \& Collson, A. R. (1977). DNA sequencing with chain termination inhibitors. Proceedings of the National Academy of Sciences of the United States of America 74, 5463-5467.

Smith, I., Paress, P., Cabane, K. \& Dubnau, E. (1980). Genetics and physiology of the rel system of Bacillus subtilis. Molecular and General Genetics 178, 271-279.

StüLke, J., Hanschke, R. \& Hecker, M. (1993). Temporal activation of $\beta$-glucanase synthesis in Bacillus subtilis is mediated by the GTP pool. Journal of General Microbiology 139, 2041-2045.

Tsukagoshi, N., Ihara, H., Yamagata, H. \& Udaka, S. (1984). Cloning and expression of a thermophilic $\alpha$-amylase gene from Bacillus stearothermophilus in Escherichia coli. Molecular and General Genetics 193, 58-63.

Vasantha, N., Thompson, D., Rhodes, C., Banner, C., Nagle, J. \& FILPULA, D. (1984). Genes for alkaline protease and neutral protease from Bacillus amyloliquefaciens contain a large open reading frame between regions coding for signal sequence and mature protein. Journal of Bacteriology 159, 811-819.

Weickert, M. J. \& Chambliss, G. H. (1990). Site-directed mutagenesis of a catabolite repression operator sequence in Bacillus subtilis. Proceedings of the National Academy of Sciences of the United States of America 87, 6238-6242.

Yanisch-Perron, C., Vieira, J. \& Messing, J. (1985). Improved M13 phage cloning vectors and host strains: nucleotide sequences of the M13mp18 and pUC19 vectors. Gene 33, 103-119. 